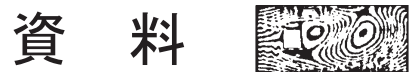

\section{Legal and Regulatory Frameworks of 195 Countries around the World with Provisions related to Wind-Resistant Design of Buildings Part 1. Africa, Americas and Asia}

\author{
Akira HAYAKAWA*1 Masahiro MATSUI*2 Yukio TAMURA*3
}

1. Introduction

Laws and regulations and their supplemental documents related to wind-resistant design of buildings for 195 countries have been collected, surveyed and screened to compile the worldwide picture on the establishment of a legal and regulatory framework related to wind-resistant design of buildings. This article gives an overview of the legal and regulatory frameworks for 137 countries of Africa, the Americas and Asia.

The findings of this study are posted on the website (URL: https://werc.t-kougei.ac.jp/TPUdatabase.html) of the Wind Engineering Research Center, Tokyo Polytechnic University, and will be updated regularly.

\section{Study Policy and Source}

\subsection{Study policy}

Laws and regulations and their supplemental documents related to wind-resistant design of buildings for a total of 195 countries, 193 of which are member states of the United Nations (UN) and 2 of which are observer states at the UN General Assembly, were targeted in this study. Among inhabited territories, Western Sahara, where sovereignty has not yet been determined, was untargeted in this study.

For each country, desk research for this collected information was carried out down to two levels of legal and regulatory system hierarchies from the national (first) level to the state or provincial (second) level. Overseas territories are included in the second level. However, if no law or regulation was identified even at the first and second levels, laws and regulations and their supplemental documents at the city (third) level were targeted only if the city was a political or economic center.

\subsection{Study source}

Online libraries of laws and regulations, official gazettes and study reports powered by national or international agencies were the main study sources. Codes, standards, guidelines and manuals developed by various authorities and institutions such as governmental agencies and academic or professional bodies were also targeted. Documents on administrative guidance and from technical consultations with authorities, project-related specification documents of public works, academic writings of every kind, and internet articles including Facebook posts were referenced as well. Furthermore, questionnaires and email interviews were conducted with related parties including consultants, researchers and officials if required.

\section{Legal and regulatory frameworks}

Legal and regulatory frameworks including provisions regarding wind-resistant design of buildings were identified in 89 of the 137 countries of Africa, the Americas and Asia. These 89 countries are shown by check marks " $\checkmark$ " in Table 1 , and their breakdown is shown for each region and subregion in Table 2. The numerical value in parentheses in these tables shows the number of countries that lie within each region and subregion. The divisions of region and subregion follow in principle the

*1 Senior Engineer, EHS \& S Research Center, NTT Facilities, Inc. akira.hayakawa.bv@ntt-f.co.jp

*2 Professor, Faculty of Engineering, Tokyo Polytechnic University

*3 Professor, School of Civil Engineering, Chongqing University 
United Nations geoscheme ${ }^{1)}$.

The legal and regulatory frameworks for 89 countries are summarized into 3 regions: 4. Africa, 5. Americas and 6. Asia. The numbers of countries in each region are 24, 28 and 37, respectively. Furthermore, each region is organized into subregions. There are 5 subregions in Africa: 4.1 Eastern Africa, 4.2 Central Africa, 4.3 Northern Africa, 4.4 Southern Africa and 4.5 West Africa. The numbers of countries in each subregion are 9, 1, 3, 5 and 6, respectively. There are 4 subregions in the Americas: 5.1 Caribbean, 5.2 Central America, 5.3 Northern America and 5.4 South America. The numbers of countries in each subregion are 8,8,2 and 10, respectively. There are 5 subregions in Asia: 6.1 Central Asia, 6.2 Eastern Asia, 6.3 South-eastern Asia, 6.4 Southern Asia and 6.5 Western Asia. The numbers of countries in each subregion are 5, 4, 7, 7 and 14, respectively.
An outline of the legal and regulatory framework is given for each country. However, if the legal and regulatory framework is identified in a superordinate legislative jurisdiction, it is not described in the subordinate legislative jurisdiction. Additionally, if the legal and regulatory framework is identified in many second and third legislative jurisdictions, it is described for only main states or provinces, overseas territories and political or economic center cities.

The document code here is unique for this study and not always the same as the official document code. For example, because the European Union (EU) standard2): Eurocode 1: Actions on structures - Part 1-4: General actions - Wind actions was published after it was translated into each mother tongue and newly numbered as a national standard of each country with its content and style unchanged, the newly numbered standards by country are represented by EN'05 to simplify the notation in sentences as well as the citation of references in this study.

Table 1. List of countries in which the legal and regulatory framework was identified

\begin{tabular}{|c|c|c|c|c|c|c|c|c|c|}
\hline \multirow{2}{*}{\multicolumn{2}{|c|}{$\begin{array}{c}\text { Africa (54) } \\
\text { Eastern Africa (18) }\end{array}$}} & Algeria & $\checkmark$ & Antigua and Barbuda & $\checkmark$ & Colombia & $\checkmark$ & Timor-Leste & - \\
\hline & & Egypt & $\checkmark$ & Bahamas & $\checkmark$ & Ecuador & $\checkmark$ & Vietnam & $\checkmark$ \\
\hline Burundi & - & Libya & - & Barbados & - & Guyana & - & \multicolumn{2}{|l|}{\begin{tabular}{|l} 
Southern Asia (9) \\
\end{tabular}} \\
\hline Comoros & - & Morocco & $\checkmark$ & Cuba & $\checkmark$ & Paraguay & $\checkmark$ & Afghanistan & - \\
\hline Djibouti & - & Sudan & - & Dominica & $\checkmark$ & Peru & $\checkmark$ & Bangladesh & $\checkmark$ \\
\hline Eritrea & - & Tunisia & - & Dominican Republic & - & Suriname & $\checkmark$ & Bhutan & $\checkmark$ \\
\hline Ethiopia & $\checkmark$ & \multicolumn{2}{|l|}{\begin{tabular}{|l} 
Southern Africa (5) \\
\end{tabular}} & Grenada & $\checkmark$ & Uruguay & - & India & $\checkmark$ \\
\hline Kenya & - & Botswana & $\checkmark$ & Haiti & - & Venezuela & $\checkmark$ & Iran & $\checkmark$ \\
\hline Madagascar & $\checkmark$ & Eswatini & $\checkmark$ & Jamaica & $\checkmark$ & \multicolumn{2}{|l|}{\begin{tabular}{|c|} 
Asia (48) \\
\end{tabular}} & Maldives & $\checkmark$ \\
\hline Malawi & $\checkmark$ & Lesotho & $\checkmark$ & St. Kitts and Nevis & $\checkmark$ & \multicolumn{2}{|l|}{ Central Asia (5) } & Nepal & $\checkmark$ \\
\hline Mauritius & - & Namibia & $\checkmark$ & St. Lucia & - & Kazakhstan & $\checkmark$ & Pakistan & $\checkmark$ \\
\hline Mozambique & $\checkmark$ & South Africa & $\checkmark$ & St. Vincent and the & $d$ & Kyrgyzstan & $\checkmark$ & Sri Lanka & - \\
\hline Rwanda & $\checkmark$ & \multicolumn{2}{|c|}{ Western Africa (16) } & Grenadines & $\sqrt{ }$ & Tajikistan & $\checkmark$ & \multicolumn{2}{|l|}{ Western Asia (18) } \\
\hline Seychelles & $\checkmark$ & Benin & - & Trinidad and Tobago & - & Turkmenistan & $\checkmark$ & Armenia & $\checkmark$ \\
\hline Somalia & - & Burkina Faso & - & Central America (8) & & Uzbekistan & $\checkmark$ & Azerbaijan & $\checkmark$ \\
\hline South Sudan & - & Cabo Verde & $\checkmark$ & Belize & $\checkmark$ & \multicolumn{2}{|l|}{ Eastern Asia (5) } & Bahrain & - \\
\hline Tanzania & $\checkmark$ & Cote d'Ivoire & $\checkmark$ & Costa Rica & $\checkmark$ & China & $\checkmark$ & Cyprus & $\checkmark$ \\
\hline Uganda & $\checkmark$ & Gambia & - & El Salvador & $\checkmark$ & Japan & $\checkmark$ & Georgia & $\checkmark$ \\
\hline Zambia & - & Ghana & $\checkmark$ & Guatemala & $\checkmark$ & Mongolia & $\checkmark$ & Iraq & $\checkmark$ \\
\hline Zimbabwe & $\checkmark$ & Guinea-Bissau & - & Honduras & $\checkmark$ & North Korea & - & Israel & $\checkmark$ \\
\hline \multicolumn{2}{|l|}{ Middle Africa (9) } & Guinea-Conakry & - & Mexico & $\checkmark$ & South Korea & $\checkmark$ & Jordan & $\checkmark$ \\
\hline Angola & $\checkmark$ & Liberia & - & Nicaragua & $\checkmark$ & \multicolumn{2}{|l|}{ South-eastern Asia (11) } & Kuwait & - \\
\hline Cameroon & - & Mali & - & Panama & $\checkmark$ & Brunei & $\checkmark$ & Lebanon & $\checkmark$ \\
\hline Central African Republic & - & Mauritania & $\checkmark$ & \multicolumn{2}{|l|}{ Northern America (2) } & Cambodia & - & Oman & - \\
\hline Chad & - & Niger & - & Canada & $\checkmark$ & Indonesia & $\checkmark$ & Palestine & $\checkmark$ \\
\hline Congo-Brazzaville & - & Nigeria & $\checkmark$ & United States & $\checkmark$ & Laos & - & Qatar & $\checkmark$ \\
\hline Congo-Kinshasa & - & Senegal & $\checkmark$ & \multicolumn{2}{|l|}{ South America (12) } & Malaysia & $\checkmark$ & Saudi Arabia & $\checkmark$ \\
\hline Equatorial Guinea & - & Sierra Leone & - & Argentina & $\checkmark$ & Myanmar & - & Syria & $\checkmark$ \\
\hline Gabon & - & Togo & - & Bolivia & $\checkmark$ & Philippines & $\checkmark$ & Turkey & $\checkmark$ \\
\hline Sao Tome and Príncipe & - & Americas (35) & & Brazil & $\checkmark$ & Singapore & $\checkmark$ & United Arab Emirates & $\checkmark$ \\
\hline Northern Africa (6) & & Caribbean (13) & & Chile & $\checkmark$ & Thailand & $\checkmark$ & Yemen & - \\
\hline
\end{tabular}

The numerical value in parentheses shows the number of countries that lie within each region and subregion. 
Table 2. Number of countries in which the legal and regulatory framework was identified

\begin{tabular}{c|c|c|c}
\hline Region & Subregion & \multicolumn{2}{|c}{ Number of countries } \\
\hline \multirow{4}{*}{$\begin{array}{c}\text { Africa } \\
\text { (54) }\end{array}$} & Eastern Africa (18) & 9 & \\
& Middle Africa (9) & 1 & \multirow{2}{*}{24} \\
& Northern Africa (6) & 3 & \multirow{2}{*}{28} \\
& Southern Africa (5) & 5 & \\
& Western Africa (16) & 6 & \\
\hline \multirow{3}{*}{$\begin{array}{c}\text { Americas } \\
\text { (35) }\end{array}$} & Caribbean (13) & 8 & \multirow{2}{*}{28} \\
& Central America (8) & 8 & \\
& Northern America (2) & 2 & \multirow{2}{*}{37} \\
& South America (12) & 10 & \\
Asia & Central Asia (5) & 5 & \\
(48) & Eastern Asia (5) & 4 & \\
& South-eastern Asia (11) & 7 & \\
& Southern Asia (9) & 7 & \\
& Western Asia (18) & 14 & \\
\hline
\end{tabular}

The numerical value in parentheses shows the number of countries that lie within each region and subregion.

\section{Africa}

4.1 Eastern Africa

(1) Ethiopia

The national standard ${ }^{3)}$ is authorized as mandatory in accordance with the Standards Agency Establishment Council of Ministers Regulation ${ }^{4}$.

(2) Madagascar

The Rules for Wind Resistant Constructions ${ }^{5}$, which require compliance with the French (FR) reference document ${ }^{6}$ : NV 65'00, are enforced in accordance with the Wind Resistant Building Construction Regulations ${ }^{7}$.

(3) Malawi

The Building Bylaws, which require buildings to withstand wind loads, are enforced in the center of commerce, Blantyre under the Local Government $\mathrm{Act}^{8)}{ }^{8)}$ ) However, the national standard $^{10)}$ is not mandatory in the Bylaws.

\section{(4) Mozambique}

The General Regulation of Urban Buildings ${ }^{11)}$ requires consideration of wind actions on metal structures. In addition, the Portuguese (PT) ministerial ordinance ${ }^{12)}$, which was enacted to extend the PT ministerial regulation ${ }^{13)}$ to overseas territories at the time of the PT overseas territory, is still inherited. ${ }^{14)}$

\section{(5) Rwanda}

The Urban Planning and Building Regulations ${ }^{15)}$, which provide the Building Code ${ }^{16)}$, are enforced under the Urban Planning and Building Law ${ }^{17)}$. Compliance with the Code is established through the national standard ${ }^{18)}$.

(6) Seychelles

The Town and Country Planning Regulations ${ }^{19)}$, which require compliance with the United Kingdom (UK) national standard ${ }^{20)}$ : BS CP3 CV2'72, are enacted under the Town and Country Planning Act ${ }^{21)}$.

(7) Tanzania

The Urban Planning Regulations ${ }^{22)}$ are enforced under the Urban Planning $\mathrm{Act}^{23)}$. Compliance with the Regulations is established through the Technical Guideline ${ }^{24)}$, which accepts BS CP3 CV2'72.

(8) Uganda

The Building Control Regulations ${ }^{25}$, which require compliance with the Structural Design Guidelines ${ }^{26}$, are enforced under the Building Control $\mathrm{Act}^{27)}$.

(9) Zimbabwe

The Building By-laws ${ }^{28)}$ are enforced in the capital, Harare under the Urban Councils Act ${ }^{29)}$. The By-laws adopt the Model Building By-laws ${ }^{30)}$, which require compliance with the Central African standard ${ }^{31)}$.

\subsection{Middle Africa}

\section{(1) Angola}

The General Regulation of Urban Buildings ${ }^{32)}$, which requires building walls to withstand winds, is enforced under the Land and Urban Planning Law ${ }^{33)}$. However, the Regulation does not define any wind-resistant requirements. EN'05 is not mandatory.

\subsection{Northern Africa}

(1) Algeria

The Snow and Wind Regulations ${ }^{34)}$ are enforced in accordance with the governmental decree ${ }^{35)}$, which establishes the powers of the responsible minster.

\section{(2) Egypt}

The Code of Practice for Calculating Loads and Forces ${ }^{36)}$ is enforced under the Law on Basis of Design and Conditions ${ }^{37)}$.

(3) Morocco

The Aseismic Construction Regulations ${ }^{38)}$, which require consideration of the most unfavorable conditions including wind effects, are enforced under the Law on Town Planning ${ }^{39)}$. However, the Regulations do not define any wind-resistant requirements. The draft Construction Code $^{40)}$, which is supposed to require compliance with EN'05 with the draft national annex ${ }^{41)}$, is not officialized.

\subsection{Southern Africa}

(1) Botswana

The Building Control Regulations ${ }^{42)}$, which accept BS CP3 CV2'72 and the ZA Standard Building Regulations ${ }^{43)}$ : SBR'70, 
are enforced under the Building Control Act ${ }^{44)}$. The national standard $^{45)}$ is not mandatory.

(2) Eswatini

The Standard Building Regulations ${ }^{46}$, which require compliance with the ZA Standard Building Regulations ${ }^{47)}$ : SBR'66, are enforced under the Building Act ${ }^{48)}$. Their revised editions $^{4955)}$, which adopt the ZA national standard ${ }^{51)}$ : SANS 10160-3'18, have not yet superseded the Act and the Regulations.

(3) Lesotho

The Building Control Regulations ${ }^{52)}$, which require buildings to withstand winds, are enforced under the Building Control Act ${ }^{53)}$. However, the Regulations do not define any wind-resistant requirements.

(4) Namibia

The Building Regulations are enacted in at least 2 municipalities under the Local Authorities Act ${ }^{54}$. Of these, the Building Regulations ${ }^{55}$, which require consideration of wind forces, are enforced in the capital, Windhoek but do not define any wind-resistant requirements. On the other hand, the Building Regulations ${ }^{56}$, which adopt SBR'70, are enforced in the largest commercial port, Walvis Bay, in accordance with section 14 bis of the Standards Act ${ }^{57}$.

(5) South Africa

The National Building Regulations ${ }^{58)}$, which require compliance with the national standard $^{51)}$ : SANS 10160-3'18, are enforced under the National Building Regulations and Building Standards $\mathrm{Act}^{59)}$.

\subsection{Western Africa}

(1) Cabo Verde

The Technical Building Code ${ }^{60)}$, which requires building walls to withstand winds, is enforced under the General Regulation of Construction and Urban Housing ${ }^{61)}$. The Code does not define any wind-resistant requirements but places top priority on compliance with PT regulations.

(2) Cote d'Ivoire

The Code of Construction and Housing ${ }^{62)}$ requires constructions to withstand strong winds. However, no relevant regulation is identified under the Code.

\section{(3) Ghana}

The National Building Regulations ${ }^{63)}$ under the Local Governance Act ${ }^{64)}$ and the Building Code ${ }^{65)}$ is accepted under the Land Use and Spatial Planning Act ${ }^{66)}$. The Regulations require compliance with the UK national standard ${ }^{67)}$ : BS CP3 CV2'70.
(4) Mauritania

The General Construction Regulations ${ }^{68)}$, which require constructions to withstand extreme climatic loads, are enforced in accordance with the ministerial decree ${ }^{69}$, which establishes the powers of the responsible minister. However, the Regulations do not define any wind-resistant requirements.

(5) Nigeria

The Building Control Regulation ${ }^{70)}$, which requires compliance with the National Building Code ${ }^{71)}$, is enforced in metropolitan Lagos under the Urban and Regional Planning and Development Law $^{72)}$. The national standard ${ }^{73)}$ is not mandatory.

(6) Senegal

The Construction Code (Regulatory part ${ }^{74)}$, which requires constructions to withstand extreme climatic loads, is enforced under the Construction Code (Legislative part) ${ }^{75)}$. However, the national standard ${ }^{76)}$ is not located under the Codes.

\section{Americas}

\subsection{Caribbean}

(1) Antigua and Barbuda

The Land Development and Control Regulations ${ }^{77)}$ are enforced under the Physical Planning $\mathrm{Act}^{78)}$. Compliance with the Regulations is established through the Building Code ${ }^{79}$, which accepts the Caribbean Building Code ${ }^{80)}$ : CUBiC'85. The Organization of Eastern Caribbean States (OECS) Building Code $^{81)}$ : OECS-BC'16, which accepts CUBiC'85, the draft Bajan (BD) national standard ${ }^{82}$ ): BNS DPC'10, the United States (US) academic society standards ${ }^{83) 84)}$ : ASCE 7'05 and ASCE 7' 10 , is not mandatory.

\section{(2) Bahamas}

The Building Code ${ }^{85}$, which requires compliance with the US academic society standard ${ }^{86)}$ : ASCE 7'88, is enforced under the Buildings Regulation $\mathrm{Act}^{87 \text { ) }}$.

(3) Cuba

The national standard for seismic effects ${ }^{88)}$, which requires consideration of the most unfavorable conditions including wind effects, is authorized as mandatory under the Decree-Law of Standardization and Quality ${ }^{89)}$. However, the national standard for wind effects ${ }^{90)}$ is not located under the Decree-Law.

(4) Dominica

The Physical Planning Act ${ }^{91)}$ requires hurricane precautions for buildings. However, the draft Building $\operatorname{Code}^{92)}$, which requires compliance with $\mathrm{CUBiC}^{\prime} 85$, is not officially located under the Act. OECS-BC'16 is not mandatory either. 
(5) Grenada

The ministerial order ${ }^{93)}$, which adopts the OECS Building Code $^{94)}$ : OECS-BC'15, is enforced under the Physical Planning and Development Control Act ${ }^{95}$. OECS-BC'15 accepts CUBiC'85, BNS DPC'10, ASCE 7'05 and ASCE 7'10.

(6) Jamaica

The national standard ${ }^{96}$, which was developed for the adoption of the US model code ${ }^{977}$ : IBC'12, is enforced as one of the National Building Codes under the Building Act ${ }^{98)}$.

(7) St. Kitts and Nevis

The Building Regulations ${ }^{99}$, which require compliance with the BD professional society standard ${ }^{100)}$ : BNS CP $28^{\prime} 81$, are enforced under the Development Control and Planning Act ${ }^{101}$. OECS-BC' 16 is not mandatory.

(8) St. Vincent and the Grenadines

The Building Regulations ${ }^{102)}$, which require compliance with CUBiC'85, are enforced under the Town and Country Planning Act ${ }^{103)}$. OECS-BC' 16 is not mandatory.

\subsection{Central America}

(1) Belize

The Building Act ${ }^{104)}$ requires hurricane precautions for buildings. However, no relevant regulation is identified under the Act.

(2) Costa Rica

The Construction Regulations ${ }^{105}$ are enforced under the Urban Planning Law ${ }^{109}$.

(3) El Salvador

The Regulations for Structural Safety of Buildings ${ }^{1077}$, which require compliance with the professional society standard $^{108)}$, are enforced under the Urban Planning and Construction Law ${ }^{109)}$.

(4) Guatemala

The Disaster Reduction Standard ${ }^{110)}$, which requires compliance with the academic society standard ${ }^{111}$, is enacted under the Law of the National Coordinator for Disaster Reduction ${ }^{112)}$.

(5) Honduras

The professional society standard ${ }^{113)}$ is adopted under the Construction Code ${ }^{114)}$.

(6) Mexico

Laws or regulations that define wind-resistant requirements for buildings are enforced in at least 6 of 32 states. Of these, the Complementary Technical Standards ${ }^{115}$, which are provided in Mexico City ${ }^{116)}$, are also adopted in Baja California ${ }^{1177}$, Baja
California Sur ${ }^{18)}$, Oaxaca ${ }^{19)(20)}$ and Tamaulipas ${ }^{121)}$ The Building Regulations ${ }^{122}$ are enforced in Tabasco.

(7) Nicaragua

The Construction Regulations ${ }^{123)}$ are enforced under the Law of Organization, Competence and Procedures of the Executive Power ${ }^{124)}$.

(8) Panama

The Structural Design Regulations ${ }^{125)}$, which require compliance with ASCE 7’05, are enforced under the Law by which the exercise of the engineering and architecture professions is regulated ${ }^{126)}$.

\subsection{Northern America}

(1) Canada

Either or both of the 2010 and 2015 editions of the National Building Codes ${ }^{127)(28)}$, which require each user's guide ${ }^{129) 130)}$, are accepted in all provinces and territories under respective acts and regulations. ${ }^{131)}$

(2) United States

Any edition of the International Building Codes ${ }^{132(97)(133) 134):}$ IBC'03, IBC'12, IBC' 15 or IBC'18, which requires any edition of the academic society standards ${ }^{135)(84) 130)}$ : ASCE 7'02, ASCE 7'10 or ASCE 7'16, is accepted in at least 43 states and the District of Columbia under respective acts and regulations. ${ }^{137)}$ Furthermore, any one of the old and new editions is also adopted in 5 unincorporated territories. Of these, in American Samoa, the Uniform Building Code ${ }^{138}$, which requires compliance with the Uniform Building Code ${ }^{139}$ : UBC'64, is enacted as a public law. In Guam and Northern Mariana Islands, the Building Code $^{140)}$ and the Building Safety Code Rules and Regulations ${ }^{141)}$, both of which require compliance with the International Building Code $^{142)}$ : IBC'09, are regarded as a public law, respectively. IBC'09 requires ASCE 7'05. In the Virgin Islands, the Building Code ${ }^{143}$, which requires compliance with IBC'03 and any subsequent updates, is enforced as a public law. In Puerto Rico, the Building Code ${ }^{144)}$, which was developed for the adoption of IBC'18, is enacted under the Law for the Reform of Permitting Process ${ }^{145)}$.

\subsection{South America}

(1) Argentina

The National Safety Regulations for Civil Works ${ }^{146}$, which include the Regulation of Wind Action on Constructions ${ }^{147}$, are enforced in accordance with the presidential decree ${ }^{148}$, which establishes the powers of the responsible ministry. 
(2) Bolivia

The Code of Urban Planning and Works ${ }^{149)}$, which accepts the municipal and national standards ${ }^{150) 151)}$, is made obligatory in metropolitan Santa Cruz de la Sierra under the Framework Law on Autonomy and Decentralization ${ }^{152}$.

(3) Brazil

The Simplified Works and Buildings Code ${ }^{153)}$, which requires compliance with national standards including the national standard for wind forces ${ }^{154)}$, is enforced to supplement the ordinary and complementary laws for metropolitan Rio de Janeiro ${ }^{155) 156)}$.

\section{(4) Chile}

The General Ordinance of Urban Planning and Constructions $^{157)}$, which requires design reviews through the withdrawn national standard ${ }^{158)}$, is enforced under the General Law of Urban Planning and Constructions ${ }^{159)}$. The current national standard ${ }^{160)}$ is not mandatory.

\section{(5) Colombia}

The Seismic Resistant Construction Regulations ${ }^{161)}$, which also define wind forces, are enacted under the Law by which norms on Earthquake Resistant Constructions are adopted ${ }^{162)}$.

\section{(6) Ecuador}

The ministerial agreement ${ }^{163)}$, which endorses the Construction Standard ${ }^{164)}$, is enforced in accordance with the Statute of Administrative Legal Regime of the Executive Function $^{165)}$.

\section{(7) Paraguay}

The General Construction Regulations ${ }^{166)}$, which require compliance with national standards including the national standard for wind actions ${ }^{167)}$, are enforced in the capital, Asuncion under the Municipal Organic Law ${ }^{168)}$.

(8) Peru

The National Building Regulations ${ }^{169)}$ are enacted under the Law of Organization and Functions of the Ministry of Housing, Construction and Sanitation ${ }^{170)}$.

(9) Suriname

The Building Ordinance ${ }^{171)}$ and Decree ${ }^{172)}$, which were enacted at the time of the Dutch constituent country, have still been enforced.

(10) Venezuela

The national standard for seismic effects ${ }^{173)}$, which requires consideration of the national standard for wind effects ${ }^{174)}$, is made obligatory under the Organic Law of the National System for Quality ${ }^{175)}$.
6. Asia

6.1 Central Asia

(1) Kazakhstan

The list of normative documents ${ }^{176}$, which includes EN'05 with the national annex ${ }^{177)}$, is promulgated under the Law on Architectural, Urban Planning and Construction Activities ${ }^{178)} .{ }^{179)}$

(2) Kyrgyzstan

The order from the responsible state agency ${ }^{180)}$, which endorses the Russian (RU) national standard ${ }^{181)}$ : SNiP 2.01.07'05, is promulgated under the Law on Technical Regulations "Safety of Buildings and Structures"182)

(3) Tajikistan

The governmental decree ${ }^{183)}$, which endorses SNiP 2.01.07'05, is promulgated for compliance with the Law on Technical Regulations ${ }^{184)}$.

(4) Turkmenistan

The Construction Norms ${ }^{185)}$, which include the ministerial standard $^{186)}$, apply under the Law on Architectural Activity ${ }^{187)}$.

(5) Uzbekistan

The list of normative documents ${ }^{188)}$, which includes the national standard ${ }^{189)}$, is promulgated under the Law on Techinical Regulations ${ }^{190)}$.

\subsection{Eastern Asia}

\section{(1) China}

The national standard ${ }^{191)}$ is enforced as one of the compulsory standards under the Standardization Law ${ }^{192)}$. At the same time, legislation is independently implemented in 2 special administrative regions. Of these, in Hong Kong, the Building (Construction) Regulations ${ }^{193)}$ are enforced under the Buildings Ordinance ${ }^{194)}$, and compliance with the Regulations is established through the Practice Notes ${ }^{195)}$, which accept the Code of Practice on Wind Effects ${ }^{196}$. In Macau, the existing Regulations on Safety and Actions in Structures of Buildings and Bridges ${ }^{197)}$ have not yet been superseded by the revised edition ${ }^{198)}$. In Taiwan, the Building Technical Regulations ${ }^{199)}$, which require compliance with the Specifications for Wind Resistant Design of Buildings $^{200)}$, are enforced under the Building Act $^{201)}$.

(2) Japan

The Building Standard Law Enforcement Order ${ }^{202)}$, which accepts two ministerial stipulations ${ }^{203) 204)}$, is promulgated under the Building Standard $\mathrm{Law}^{205)}$. The academic society standard ${ }^{206)}$ is not mandatory.

(3) Mongolia

The Code on Loads and Reactions ${ }^{207)}$ and the Climatic and 
Geophysical Parameters for Construction ${ }^{208)}$ become a part of the General System of Norms and Normative Documents for Construction $^{209)}$ under the Law on Construction ${ }^{210)}$. The national standard ${ }^{211)}$ and EN'05 are not mandatory.

\section{(4) South Korea}

The Building Structural Standards Rules ${ }^{212)}$, which require compliance with the Building Structural Standards ${ }^{213)}$, are enacted under the Building Law ${ }^{214)}$.

\subsection{South-eastern Asia}

\section{(1) Brunei}

The Building Control Regulations ${ }^{215)}$ are enforced under the Building Control Order ${ }^{216}$. Compliance with the Regulations is established through the Building Guidelines and Requirements $^{217)}$, which accept BS CP3 CV2'72, the UK national standard ${ }^{218)}$ : BS 6399.2'97 and EN'05 with the UK national annex ${ }^{219)}$

(2) Indonesia

The Implementing Regulations ${ }^{220)}$ are enforced under the Law on Buildings ${ }^{221)}$. Compliance with the Regulations is established through the Guidelines for Building Technical Requirements ${ }^{222)}$, which accept the withdrawn national standard $^{223)}$. The current national standard ${ }^{224)}$ is not mandatory. (3) Malaysia

Ordinances or by-laws that define wind-resistant requirements for buildings are enforced in at least 5 of 16 states and federal territories under the Street, Drainage and Building $\mathrm{Act}^{225)}$. Of these, the Uniform Building By-Laws ${ }^{226}$, which require compliance with $\mathrm{BS}$ CP3 CV2'72, are adopted in Johor $^{227)}$ and the Federal Territory of Kuala Lumpur ${ }^{228)}$, and the Buildings Ordinance ${ }^{229)}$, which requires compliance with BS 6399.2'97, is enforced in Sarawak. The Uniform Building ByLaws, which require compliance with the national standard ${ }^{230)}$, are enforced in Melaka ${ }^{231)}$ and Selangor ${ }^{232)}$. EN'05 is not mandatory.

\section{(4) Philippines}

The National Building Code ${ }^{233)}$, which requires compliance with the professional society code ${ }^{234)}$, is enforced in accordance with its Implementing Rules and Regulations ${ }^{235)}$.

\section{(5) Singapore}

The Building Control Regulations ${ }^{236}$ are enforced under the Building Control $\mathrm{Act}^{237}$. Compliance with the Regulations is established through the Approved Document ${ }^{238)}$, which accepts BS CP3 CV2'72, BS 6399.2'97 and EN'05 with the national annex ${ }^{239)}$.
(6) Thailand

The ministerial regulations ${ }^{240}$ are enforced under the Building Control Act ${ }^{241)}$. The ministerial standard ${ }^{242)}$ is not mandatory.

(7) Vietnam

The Building Code ${ }^{243)}$, which requires compliance with the national standard ${ }^{244)}$, and the National Technical Regulations ${ }^{245)}$ are enacted in accordance with the governmental decree ${ }^{246)}$, which establishes the functions and tasks of the responsible ministry. EN'05 is not mandatory.

\subsection{Southern Asia}

\section{(1) Bangladesh}

The National Building Code ${ }^{247)}$ is enforced under the Building Construction Act $^{248)}$.

(2) Bhutan

The Building Regulation ${ }^{249)}$ is enforced under the Local Government $\mathrm{Act}^{250)}$. Compliance with the Regulation is established through the Building Code $^{251)}$, which accepts the Indian national standard ${ }^{252)}$ : IS 875.3'87.

\section{(3) India}

Bye-laws or rules that define wind-resistant requirements for buildings are enacted in at least 8 of 36 states and union territories. Of these, the National Building Code ${ }^{253)}$ and the national standard ${ }^{254)}$ : IS 875.3'15 are adopted in Andhra Pradesh $^{255)}$, Karnataka ${ }^{256)}$, Maharashtra ${ }^{257)}$, Tamil Nadu ${ }^{258)}$, West Bengal $^{259)}$ and the National Capital Territory of Delhi ${ }^{260)}$. The withdrawn National Building Code ${ }^{261}$ and the withdrawn national standard ${ }^{252)}$ : IS 875.3'87 are still enforceable in Bihar ${ }^{262}$ and Jharkhand ${ }^{263)}$.

(4) Iran

Compliance with the National Building Regulations ${ }^{264)}$ is deemed to be equivalent to compliance with the Law on Engineering System and Building Control ${ }^{265)}$. The national standard ${ }^{266)}$ is not mandatory.

(5) Maldives

The National Building Code ${ }^{267)}$, which requires buildings to withstand winds, is enforced under the Construction $\mathrm{Act}^{268)}$. The draft Approved Document ${ }^{269)}$, which accepts BS 6399.2'97, is not endorsed as mandatory for compliance with the Code.

(6) Nepal

The National Building Code ${ }^{270)}$, which requires compliance with IS 875.3'87, is enforced under the Building Act ${ }^{271)}$.

(7) Pakistan

Regulations or bye-laws that accept one or more of the US 
model codes, the UK national standards and the ministerial $\operatorname{code}^{272)}$ are enacted in at least 5 of 7 provinces, and autonomous and federal territories. For example, the UK national standard $^{273)}$ : BS CP3 CV'52 and the ministerial code are accepted in the Islamabad Capital Territory ${ }^{274) 275)}$, and the US model codes or the UK national standards approved by the responsible authority are commonly accepted in Khyber Pakhtunkhwa $^{276)}$ and Sindh $^{277)}$. In Punjab, where multiple responsible authorities are established, the requirements of UBC'97, the US model code ${ }^{278)}$ : IBC'06 and the ministerial code shall be met in metropolitan Lahore ${ }^{279)}$. In Azad Jammu and Kashmir, the ministerial code, UBC'97, IBC'03 and IBC'06 shall apply with proper engineering judgment. ${ }^{280)}$ IBC'06 requires ASCE 7'05.

\subsection{Western Asia}

\section{(1) Armenia}

The Normative Acts Regulations ${ }^{281}$, which require compliance with the RU national standard ${ }^{282)}$ : SNiP 2.01.07'88, and the Construction Norms ${ }^{283}$ are enforced under the Law on Urban Development ${ }^{284}$.

\section{(2) Azerbaijan}

The list of normative documents ${ }^{285}$, which includes the construction standard ${ }^{286}$, is promulgated under the Urban Building and Construction Code ${ }^{287)}$.

\section{(3) Cyprus}

The Road and Building Regulations ${ }^{288)}$, which require compliance with EN'05 with the national annex ${ }^{289)}$, are enforced under the Road and Building Regulations Law ${ }^{290)}$.

\section{(4) Georgia}

The Construction Norms and Rules ${ }^{291)}$, which require compliance with SNiP 2.01.07'88, and the Design Norms on Construction Climatology ${ }^{292)}$ are enforced under the Law on Normative Acts ${ }^{293)}$ and the Law on Construction Activities ${ }^{294)}$, respectively. EN'05 is not mandatory.

(5) Iraq

The Code of Loads and Forces ${ }^{295)}$ is enacted as one of the Building Codes under the Law on Central Organization for Standardization and Quality Control ${ }^{296)}$.

(6) Israel

The Planning and Building Regulations ${ }^{297)}$, which require compliance with the national standard ${ }^{298)}$, are enforced under the Planning and Building Law ${ }^{299)}$.

(7) Jordan

The National Building $\operatorname{Code}^{300)}$ are enacted in accordance with the Instructions of Codes Application ${ }^{301)}$ under the National Construction $\mathrm{Law}^{302)}$.

(8) Lebanon

The Public Safety Law ${ }^{303)}$, which accepts standards and specifications of EU countries, the US and Canada, is enforced under the Construction $\mathrm{Law}^{304)}$. The national standard ${ }^{305)}$ is not mandatory.

(9) Palestine

The Regulation on Multistory Buildings ${ }^{306)}$, which requires buildings to withstand winds, is enforced in the Gaza Strip under the Town Planning Law ${ }^{307)}$. However, the Regulation does not define any wind-resistant requirements.

(10) Qatar

The Construction Specifications ${ }^{308)}$, which accept ASCE 7'05, IBC'12, BS 6399.2'97 and EN'05 with the UK national annex, are enforced under the Law on Building Regulations ${ }^{309)}$.

(11) Saudi Arabia

The Building Code ${ }^{310)}$ is enforced in accordance with the Implementing Regulations ${ }^{311)}$.

(12) Syria

The Building Code ${ }^{312)}$ is enforced in the capital, Damascus under the Local Administration Law ${ }^{313)}$. Compliance with the Code is established through the professional society codes ${ }^{314) 315)}$.

(13) Turkey

The Regulations for Buildings to be built in Disaster Areas $^{316)}$, which require consideration of the most unfavorable conditions of seismic or wind effects, are enforced under the Law on Aid and Measures to be taken due to Disasters affecting Public Life $^{317)}$. However, the municipal regulations for metropolitan Istanbul $^{318)}$, the national standard ${ }^{319)}$ and EN'05 are not mandatory. (14) United Arab Emirates

Codes or regulations that define wind-resistant requirements for buildings are enforced in at least 3 of 7 emirates. Of these, in Abu Dhabi ${ }^{320) 321)}$ and Ras Al Khaimah ${ }^{322)}$, the Building Codes both accept ASCE 7'05. In Dubai, the municipal regulations ${ }^{323}$ and circular $^{324}$ accept the municipal Wind Code $^{325)}$, BS 6399.2'97, and ASCE 7'05 and its subsequent editions.

\section{Summary}

Laws and regulations and their supplemental documents related to wind-resistant design of buildings for 195 countries have been investigated to compile the worldwide picture on the establishment of the legal and regulatory framework related to wind-resistant design of buildings. This article gives an 
overview of the legal and regulatory frameworks for 137 countries of Africa, the Americas and Asia. The findings are summarized as follows.

- Legal and regulatory frameworks including provisions regarding wind-resistant design of buildings were identified in 89 of the 137 countries of Africa, the Americas and Asia.

- $\quad$ For Africa, 24 of 54 countries have established legal and regulatory frameworks. This comprises just $44 \%$ of the regional total. In particular, in Middle Africa, no legal and regulatory framework was identified in 8 of 9 countries.

- $\quad$ For the Americas, 28 of 35 countries have established legal and regulatory frameworks. This accounts for $80 \%$ of the regional total.

- $\quad$ For Asia, 37 of 48 countries have established legal and regulatory frameworks. This accounts for $77 \%$ of the regional total.

\section{Acknowledgements}

This study was implemented with the supports of many consultants, researchers, and officers around the world. The authors would like to take this opportunity to thank all of them, especially, Dr. Adam Goliger (South Africa), Ms. Carla Martin (Cabo Verde), Mr. Claus Heydenrych (Namibia), Mr. Gert Wentzel (Angola), Mr. Graeme McRae-Samuel (Angola), Mr. Harry Deodharry (Guyana), Mr. Matthew Lammers (Uganda), Prof. Mohamed Ziara (Palestine), Dr. Neelamani Subramaniam (Kuwait), Dr. Noram Irwan Ramli (Malaysia), Mr. Rachid Moubarak (Lebanon), Dr. Saw Htwe Zaw (Myanmar), Mr. Terangue Gillham (Guam, US), Mr. Tony Gibbs (Trinidad and Tobago), Mr. Yee Wan Chung (Brunei), Mr. Yeshey Lotay (Bhutan) and Mr. Yessenia Romero (Bolivia), for providing valuable information on wind-resistant design of buildings for countries in Africa, the Americas and Asia.

For continuous information updates, the authors would appreciate receiving new information on laws, regulations, codes or standards related to wind-resistant design of buildings by email to jurc_office@arch.t-kougei.ac.jp.

\section{References}

1) UNSD (United Nations Statistics Division), "Geographic Regions - Standard country or area codes for statistical use (M49)", (1999), https://unstats.un.org/unsd/methodology/ m49/ (accessed December 7, 2019)

2) $\mathrm{CEN}$ (European Committee for Standardization), "Eurocode
1: Actions on structures - Part 1-4: General actions - Wind actions", EN 1991-1-4:2005, Brussels, Belgium, (2005)

3) ESA (Ethiopian Standard Agency), "Actions on Structures - Part 1-4: General Actions - Wind Actions", CES 145: 2015, Addis Ababa, Ethiopia, (2015)

4) CMET (Council of Ministers), "Ethiopian Standards Agency Establishment Council of Ministers Regulation", No. 193, Addis Ababa, Ethiopia, (2010)

5) CPGU (Cellule de Prevention et Gestion des Urgences), "Regles et Fascicule pour Constructions para cycloniques a Madagascar [French]", Antananarivo, Madagascar, (2018)

6) CSTB (Centre Scientifique et Technique du Batiment), "Regles definissant les effets de la neige et du vent sur les constructions et annexes [French]", Regles NV 65, Champs-sur-Marne, France, (2000)

7) GMG (Gouvernement de Madagascar), "Règlements de construction de bâtiment paracyclonique [French]", Decret No. 2010-0243, Antananarivo, Madagascar, (2010)

8) "Local Government Act, 1998", No. 42, Lilongwe, Malawi, (1998)

9) WB (World Bank), "Managing Risks for a Safer Built Environment in Malawi. Building Regulatory Capacity Assessment", Washington, D.C., United States, (2019)

10) MBS (Malawi Bureau of Standards), "Code of practice for design loadings for buildings", MS 820:2010, Blantyre, Malawi, (2010)

11) DSOPT (Direcção dos Serviços de Obras Pública e Transportes), "Regulamento Geral de Edificacoes Urbanas [Portuguese]", Diploma Legislativo n 1976, Lourenço Marques, Moçambique, (1960)

12) MU (Ministério do Ultramar), "Portaria n. ${ }^{\circ} 19053$ extensivo ao ultramar o Decreto n. ${ }^{\circ} 44041$, de 18 de Novembro de 1961 [Portuguese]", Lisbon, Portugal, (1962)

13) MOP (Ministério das Obras Públicas), "Regulamento de Solicitações em Edifícios e Pontes [Portuguese]", Decreto no. 44041, Lisbon, Portugal, (1961)

14) C.B.C. Dgedge, "Avaliacao da Seguranca Estrutural Usando Regulamentos Portugueses e Sul africanos: Estudo Comparativo [Portuguese]", Instituto Superior Politécnico e Universitário de Nacala, (2015)

15) MINIFRA (Ministry of Infrastructure), "Urban Planning and Building Regulations", Order N03/CAB.M/019, Kigali, Rwanda, (2019)

16) MINIFRA (Ministry of Infrastructure), "Rwanda Building 
Code", Kigali, Rwanda, (2019)

17) "Urban Planning and Building Law", No. 10/2012, Kigali, Rwanda, (2012)

18) RSB (Rwanda Standards Board), "Structural design - Part 2: Action on structures - Wind actions", RS 114-2, Kigali, Rwanda, (2011)

19) GSC (Government of Seychelles), "Town and Country Planning (Building) Regulations", Victoria, Seychelles, (1975)

20) BSI (British Standards Institution), "Code of Basic data for the design of buildings - Chapter V: Loading - Part 2: Wind Loads", BS CP 3: Chapter V-2, London, United Kingdom, (1972)

21) "Town and Country Planning Act", Chapter 237, Victoria, Seychelles, (1972)

22) MLHHSD (Ministry of Land, Housing and Human Settlement Development), "Urban Planning (Building) Regulations, 2018", Government Notice No. 80, Dodoma, Tanzania, (2018)

23) "Urban Planning Act, 2007", Chapter 355, Dodoma, Tanzania, (2007)

24) MLHHSD (Ministry of Lands, Housing and Human Settlements Development), "BRU Technical Guideline No. 2 - Loads for Structural Design", Dar es Salaam, Tanzania, (2015)

25) MWT (Ministry of Works and Transport), "Building Control Regulations", Kampala, Uganda, (2012)

26) MWHC (Ministry of Works, Housing and Communications), "Structural Design Guidelines", Kampala, Uganda, (2005)

27) "Building Control Act", No. 10, Kampala, Uganda, (2013)

28) MLGUD (Ministry of Local Government and Urban Development), "Building (Adoption) By-laws", No.36, Harare, Zimbabwe, (1979)

29) "Urban Councils Act [Chapter 29:15]", Harare, Zimbabwe, (1995)

30) MLH (Ministry of Local Government and Housing), "Model Building By-laws 1977", Rhodesia Government Notice No.41, Harare, Zimbabwe, (1978)

31) CASI (Central African Standards Institution), "Basic data for the design of buildings: Loads and forces. Pt 2 Wind Loads", CAS 160.2, Harare, Zimbabwe, (1977)

32) MUHAO (Ministério do Urbanismo e Habitação), "Regulamento Geral das Edificações Urbanas", Decreto Executivo n. ${ }^{\circ}$ 13/07, Luanda, Angola, (2007)
33) "Land and Urban Planning Law [Portuguese]", Lei nº. 3/04, Luanda, Angola, (2004)

34) MHUV (Ministre de l'Habitat et de l'Urbanisme et de la Ville), "Reglement Neige et Vent «RNV/Version $2013 »$ [French]", Arrêté du 7 Chaâbane 1434, Algiers, Algeria, (2013)

35) GDZ (Gouvernement de l'Algérie), "Décret exécutif nº8189 fixant les attributions du ministre de l'habitat et de l'urbanisme [French]", Algiers, Algeria, (2008)

36) MHUUC (Ministry of Housing, Utilities and Urban Communities), "Egyptian Code of Practice for Calculating Loads and Forces in Structural and Building Works [Arabic]", ECP-201:2012, Decision No. 431, Cairo, Egypt, (2012)

37) "Law on Basis of Design and Conditions [Arabic]", No. 6, Cairo, Egypt, (1964)

38) MHPV (Ministère de l'Habitat et de la Politique de la Ville), "Règlement de Construction Parasismique [French]", RPS 2000, Décret n 2-12-682 du 17 rejeb 1434, Rabat, Maroc, (2011)

39) "Law on Town Planning [French]", Loi n 12-90, Rabat, Maroc, (1992)

40) MHPV (Ministere de l'Habitat et de la Politique de la Ville), "Projet du Code de la Construction [French]", Rabat, Maroc, (2015)

41) IMANOR (Institut Marocain de Normalisation), "Eurocode 1 : Actions sur les structures - Partie 1-4 : Actions générales - Actions du vent [French]", PNM EN 1991-1-4, Rabat, Maroc, (2020)

42) GBW (Government of Botswana), "Building Control Regulations", Gabonore, Botswana, (1981)

43) DICT (Department of Industries, Commerce, and Tourism), "Standard Building Regulations", Cape Town, South Africa, (1970)

44) "Building Control Act", Chapter 65:02, Gaborone, Botswana, (1981)

45) BOBS (Botswana Bureau of Standards), "Basics of structural design and actions for buildings and Industrial structures - Part 3: Wind actions", BOS 536-3:2014, Gaborone, Botswana, (2014)

46) GSZ (Government of Swaziland), "Standard Building Regulations, 1969", Mbabane, Swaziland, (1969)

47) SABS (South African Bureau of Standards), "Standard Building Regulations", Pretoria, South Africa, (1966)

48) "Building Act, 1968", No. 34, Mbabane, Swaziland, (1968) 
49) SCG(Swaziland Consulting Engineers), "National Building Act", Final Draft, Mbabane, Swaziland, (2018)

50) SCG (Swaziland Consulting Engineers), "National Building Regulations", Final Draft, Mbabane, Swaziland, (2018)

51) SABS (South African Bureau of Standards), "Basis of structural design and actions for buildings and industrial structures - Part 3: Wind actions", SANS 10160-3:2018, Pretoria, South Africa, (2018)

52) MLGLS (Ministry of Local Government), "Building Control (Building Site Operations and Building Design and Construction) Regulations 1999", Government Notice No. 1, Maseru, Lesotho, (1999)

53) "Building Control Act 1995", No. 8, Maseru, Lesotho, (1995)

54) "Local Authorities Act, 1992", No.23, Windhoek, Namibia, (1992)

55) MCWH (Municipal Council of Windhoek), "Building Regulations", Government Notice No. 57, Windhoek, Namibia, (1969)

56) MCWB (Municipality Council of Walvis Bay), "Adoption of Standard Building Regulations", Order No. 303, Walvis Bay, Namibia, (1995)

57) "Standards Act, 1962", No. 72, Cape Town, South Africa, (1964)

58) SABS (South African Bureau of Standards), "Code of Practice for the Application of the National Building Regulations", SABS 0400, Pretoria, South Africa, (1990)

59) "National Building Regulations and Building Standards Act, 1977", No. 103, Cape Town, South Africa, (1977)

60) MIEM/MAOT (Ministerio das Infraestruturas e Economia Maritima e Ministerio do Ambiente e Ordenamento do Territorio), "Código Técnico da Edificação (CTE) [Portuguese]", Praia, Cabo Verde, (2012)

61) $\mathrm{CMCV}$ (Conselho de Ministros), "Regulamento Geral de Construcao e Habitacao Urbana [Portuguese]", DecretoLei n ${ }^{\circ}$ 18/2011, Praia, Cabo Verde, (2011)

62) "Code of Construction and Housing [French]", Loi ${ }^{\circ}$ 2019-576, Abidjan, Cote d'Ivoire, (2019)

63) MWHGH (Ministry of Works and Housing), "National Building Regulations 1996", Legislative Instrument No. 1630, Accra, Ghana, (1996)

64) "Local Governance Act, 2016", No. 936, Accra, Ghana, (2016)

65) GSA (Ghana Standards Authority), "Ghana Building Code", GS 1207:2018, Accra, Ghana, (2018)
66) "Land Use and Spatial Planning Act, 2016", No. 925, Accra, Ghana, (2016)

67) BSI (British Standards Institution), "Code of Basic data for the design of buildings - Chapter V: Loading - Part 2: Wind Loads", BS CP 3: Chapter V-2, London, United Kingdom, (1970)

68) MEUHAR (Ministère de l'Equipement, de l'Urbanisme et de l'Habitat Actes Réglementaires), "Règlement Général de la Construction [French]", Décret n ${ }^{\circ}$ 2007-205, Nouakchott, Mauritania, (2007)

69) MHUAT (Ministere de l'Habitat de l'Urbanisme et de l'Aménagement du Territoire), "Décret n001-2020 du 14 janvier 2020, fixant les attributions du Ministre de l'Habitat, de l'Urbanisme et de l'Aménagement du Territoire et l'organisation de l'Administration Centrale de son Département [French]", Nouakchott, Mauritania, (2020)

70) MPPUD (Ministry of Physical Planning and Urban Development - Lagos State), "Lagos State Building Control Regulation, 2019", Lagos, Nigeria, (2019)

71) FMLHUD (Federal Ministry of Lands, Housing and Urban Development), "National Building Code of Nigeria", Abuja, Nigeria, (2006)

72) LSHA (Lagos State House of Assembly), "Lagos State Urban and Regional Planning and Development Law", Lagos, Nigeria, (2010)

73) SON (Standards Organization of Nigeria), "Standard Code of Practice - Part 3: Loading", NCP 001-3:1973, Abuja, Nigeria, (1973)

74) GSN (Government of Senegal), "Code de la Construction (Partie reglementaire) [French]", Decret n 2010-99, Dakar, Senegal, (2010)

75) "Construction Code (Legislative part) [French]", Loi $n^{\circ}$ 2009-23, Dakar, Senegal, (2009)

76) ASN (Association Senegalaise de Normalisation), "Regles Senevent: Methode d'evaluation des efforts du vent sur les constructions au Senegal [French]", NS 02-058:2008, Dakar, Senegal, (2008)

77) MWHAG (Ministry of Works and Housing), "Land Development and Control Regulations 1996", Statutory Instrument No. 20, St. John's, Antigua and Barbuda, (1996)

78) "Physical Planning Act, 2003", No. 3, St. John's, Antigua and Barbuda, (2003)

79) DCA (Development Control Authority), "Antigua and Barbuda Building Code", St. John’s, Antigua and Barbuda, 
(1995)

80) CARICOM (Caribbean Community Secretariat), "Caribbean Uniform Building Code (CUBiC)", Georgetown, Guyana, (1985)

81) OECS (Organization of Eastern Caribbean States Secretariat), "OECS Building Code", Castries, St. Lucia, (2016)

82) BNSI (Barbados National Standards Institution), "Code of Practice for Wind Loads for Structural Design", Final Draft, BNS/DPC 2010-001, St. Michael, Barbados, (2010)

83) ASCE (American Society of Civil Engineers), "Minimum Design Loads for Buildings and Other Structures", ASCE/ SEI 7-05, Reston, United States, (2005)

84) ASCE (American Society of Civil Engineers), "Minimum Design Loads for Buildings and Other Structures", ASCE/ SEI 7-10, Reston, United States, (2010)

85) MWU (Ministry of Works and Utilities), "Bahamas Building Code", Nassau, Bahamas, (2003)

86) ASCE (American Society of Civil Engineers), "Minimum Design Loads for Buildings and Other Structures", ANSI/ ASCE 7-88, Reston, United States, (1990)

87) "Buildings Regulation Act", Chapter 200, Nassau, Bahamas, (1971)

88) NC (Cuban National Bureau of Standards), "Earthquake resistant construction - Basic requirements for design and construction [Spanish]", NC 46:2017, Habana, Cuba, (2017)

89) CMCU (Consejo de Ministros), "Decreto-Ley No. $182 \mathrm{de}$ Normalización y Calidad [Spanish]", Habana, Cuba, (1998)

90) NC (Cuban National Bureau of Standards), "Wind action on structures. Calculation method [Spanish]", NC 283: 2003, Habana, Cuba, (2003)

91) "Physical Planning Act, 2002", No.5, Roseau, Dominica, (2002)

92) PPDA (Physical Planning and Development Authority), "Commonwealth of Dominica Building Code", Roseau, Dominica, (1996)

93) PDA (Planning and Development Authority), "Physical Planning and Development Control (Adoption of Building Code) Order", Statutory Rules and Orders No. 42, St. George's, Grenada, (2016)

94) OECS (Organization of Eastern Caribbean States Secretariat), "OECS Building Code", Castries, St. Lucia, (2015)

95) "Physical Planning and Development Control Act 2002", No. 25, St. George's, Grenada, (2002)

96) BSJ (Bureau of Standards Jamaica), "Application Document for the International Building Code", JS 306:2017, Kingston, Jamaica, (2017)

97) ICC (International Code Council), "International Building Code", IBC 2012, Washington, D.C., United States, (2012)

98) "Building Act, 2018", No.3, Kingston, Jamaica, (2018)

99) GKN (Government of St. Kitts and Nevis), "Building Regulations", Statutory Rules and Orders No. 7, Basseterre, St. Kitts and Nevis, (2002)

100) BAPE (Barbados Association of Professional Engineers), "Code of Practice for Wind Loads for Structural Design", St. Michael, Barbados, (1981)

101) "Development Control and Planning Act", Chapter 20.07, Basseterre, St. Kitts and Nevis, (2002)

102) MHVC (Ministry of Housing), "Building Regulations, 2008", Statutory Rules and Orders No. 43, Kingstown, St. Vincent and the Grenadines, (2008)

103) "Town and Country Planning Act, 1992", No. 45, Kingstown, St. Vincent and the Grenadines, (1992)

104) "Belize Building Act", Chapter 131, Belmopan, Belize, (2011)

105) INVU (Instituto Nacional de Vivienda y Urbanismo), "Reglamento de Construcciones [Spanish]", San Jose, Costa Rica, (1983)

106) "Urban Planning Law [Spanish]", No. 4240, San Jose, Costa Rica, (2010)

107) MOPTVDU (Ministerio de Obras Publicas, Transporte, Vivienda y Desarrollo Urbano), "Reglamento para la Seguridad Estructural de las Construcciones [Spanish]", Decreto No. 105, San Salvador, El Salvador, (1996)

108) ASIA (Asociacion Salvadorena de Ingenieros y Arquitectos), "Norma Tecnica para Diseno por Viento y sus Comentarios [Spanish]", San Salvador, El Salvador, (1997)

109) "Urban Planning and Construction Law [Spanish]", Decreto Legislativo No. 232, San Salvador, El Salvador, (1951)

110) CONRED (Coordinadora Nacional para la Reducción de Desastres), "Norma para le Reducción de Desastres Numero Uno [Spanish]", NRD-1, Acuerdo No. 03-2010, Ciudad de Guatemara, Guatemala, (2010)

111) AGIES (Guatemalan Association of Structural and Seismic Engineering), "Demandas Estructurales, Condiciones de Sitio y Niveles de Proteccion [Spanish]", AGIES NSE 210, Santa Catarina Pinula, Guatemala, (2010)

112) "Law of the National Coordinator for Disaster Reduction [Spanish]", Decreto Numero 109-96, Ciudad de Guatemara, 
Guatemala, (1996)

113) $\mathrm{CICH}$ (Colegio de Ingenieros Civiles de Honduras), "Codigo Hondureno de Construccion - Normas Technica [Spanish]", CHOC-08, Tegucigalpa, Honduras, (2008)

114) "Construction Code [Spanish]", Decreta No. 173-2010, Tegucigalpa, Honduras, (2010)

115) GDF (Gobierno de la Ciudad de México), "Norma Técnica Complementaria para la Revisión de la Seguridad Estructural de las Edificaciones [Spanish]", NTC-RSEE 2017, Ciudad de México, México, (2017)

116) GDF (Gobierno de la Ciudad de México), "Reglamento de Construcciones para el Distrito Federal [Spanish]", Ciudad de México, México, (2016)

117) CBC (Congreso del Estado de Baja California), "Ley de Edificaciones del Estado de Baja California [Spanish]", Mexicali, Mexico, (2018)

118) GBCS (Gobierno del Estado de Baja California Sur), "Reglamento de Construcciones para el Estado de Baja California Sur [Spanish]", (2005)

119) GOA (Gobierno del Estado de Oaxaca), "Reglamento de Construcción y Seguridad Estructural para el Estado de Oaxaca [Spanish]", Oaxaca de Juárez, México, (1998)

120) CEOTDU (Consejo Estatal de Ordenamiento Territorial y Desarrollo Urbano), "Normas Técnicas Complementarias de Emergencia para Diseño por Viento [Spanish]", Oaxaca de Juárez, Mexico, (2019)

121) GTM (Gobierno del Estado de Tamaulipas), "Reglamento de Construcciones para el Estado de Tamaulipas [Spanish]", Ciudad Victoria, Mexico, (2012)

122) GTB (Gobierno del Estado de Tabasco), "Reglamento de Construcciones del Estado de Tabasco [Spanish]", Villahermosa, Mexico, (1975)

123) MTI (Ministerio de Transporte e Infraestructura), "Reglamento Nacional de Construccion [Spanish]", Resolución No. 01, Managua, Nicaragua, (2007)

124) "Law of Organization, Competence and Procedures of the Executive Power [Spanish]", No. 290, Managua, Nicaragua, (2006)

125) JTIA (Junta Tecnica de Ingenieria y Arquitectura), "Reglamento de Diseno Estructural para la Republica de Panama [Spanish]", REP-2014, Resolución No. JTIA-1872015, Panama City, Panama, (2015)

126) "Law by which the exercise of the engineering and architecture professions is regulated [Spanish]", No. 15,
Panama City, Panama, (1959)

127) NRC (National Research Council of Canada), "National Building Code of Canada 2010", Ottawa, Canada, (2010)

128) NRC (National Research Council of Canada), "National Building Code of Canada 2015", Ottawa, Canada, (2015)

129) NRC (National Research Council of Canada), "User's Guide - NBC 2010, Structural Commentaries (Part 4 of Division B)", Ottawa, Canada, (2011)

130) NRC (National Research Council of Canada), "Structural Commentaries (User's Guide - NBC 2015: Part 4 of Division B)", Ottawa, Canada, (2017)

131) NRC (National Research Council of Canada), "Model code adoption across Canada", (2019), https://nrc.canada.ca/ en/certifications-evaluations-standards/codes-canada/model -code-adoption-across-canada (accessed February 24, 2020)

132) ICC (International Code Council), "International Building Code", IBC 2003, Washington, D.C., United States, (2003)

133) ICC (International Code Council), "International Building Code", IBC 2015, Washington, D.C., United States, (2015)

134) ICC (International Code Council), "International Building Code", IBC 2018, Washington, D.C., United States, (2018)

135) ASCE (American Society of Civil Engineers), "Minimum Design Loads for Buildings and Other Structures", SEI/ ASCE 7-02, Reston, United States, (2002)

136) ASCE (American Society of Civil Engineers), "Minimum Design Loads for Buildings and Other Structures", ASCE/ SEI 7-16, Reston, United States, (2016)

137) ICC (International Code Council), "International CodesAdoption by State (OCT 2019)", Washington, D.C., United States, (2019)

138) "Uniform Building Code", Public Law No. 11-50, Pago Pago, American Samoa, (1969)

139) ICBO (International Conference of Building Officials), "Uniform Building Code", Whittier, United States, (1964)

140) "Building Code", Public Law 30-199, Agana, Guam, (2010)

141) "Building Safety Code Rules and Regulations", Chapter 155-10.1, Saipan, Northern Mariana Islands, (2009)

142) ICC (International Code Council), "International Building Code", IBC 2009, Washington, D.C., United States, (2009)

143) "Building Code", Chapterp 5, Title 29, Charlotte Amalie, US Virgin Islands, (2018)

144) PRCCC (Puerto Rico Comstruction Code Committe), "Puerto Rico Building Code", Orden Administrativa OGPe 2011-16, San Juan, Puerto Rico, (2018) 
145) "Law for the Reform of Permitting Process [Spanish]", No. 161-2009, San Juan, Puerto Rico, (2009)

146) SOP (Secretaría de Obras Públicas), "Reglamentos desarrollados por el Centro de Investigación de los Reglamentos Nacionales de Seguridad para las Obras Civiles [Spanish]", Resolución 247/2012, Buenos Aires, Argentina, (2012)

147) CIRSOC (Centro de Investigación de los Reglamentos Nacionales de Seguridad para las Obras Civiles), "Reglamento Argentino de Acción del Viento sobre las Construcciones y sus Comentarios [Spanish]", CIRSOC 102-2005, Buenos Aires, Argentina, (2005)

148) PAR (Presidente de la Nacion Argentina), "Apruébase la estructura organizativa del primer nivel operativo del citado Departamento de Estado y modifícanse los Objetivos de los niveles políticos del Organigrama de Aplicación de la Administración Centralizada [Spanish]", Decreto 1142/2003, Buenos Aires, Argentina, (2003)

149) GSS (Gobierno Autonomo Municipal de Santa Cruz de la Sierra), "Código de Urbanismo y Obras [Spanish]", Ley Autonomic a Municipal Gamscs Nº 059, Santa Cruz de la Sierra, Bolivia, (2015)

150) CICS (Colegio de Ingenieros Civiles de Santa Cruz), "Acciones de viento sobre las construcciones [Spanish]", CIC 103, Santa Cruz, Bolivia, (2012)

151) IBNORCA (Instituto Boliviano de Normalizacion y Calidad), "Acciones sobre las estructuras - Accion del viento - Parte 1: Especializaciones y Parte 2: Comentarios [Spanish]", NB 1225003-1/2:2014, La Paz, Bolivia, (2015)

152) "Framework Law on Autonomy and Decentralization [Spanish]", N 031, La Paz, Bolivia, (2010)

153) GRJ (Governo do Estado do Rio de Janeiro), "Institui o Código de Obras e Edificações Simplificado do Município do Rio de Janeiro - COES [Portuguese]", Lei Complementar No 198 DE 14/01/2019, Rio de Janeiro, Brasil, (2019)

154) ABNT (Associação Brasileira de Normas Técnicas), "Forças devidas ao vento em edificações [Portuguese]", Versao Corrigida 2:2013, ABNT NBR 6123:1988, Rio de Janeiro, Brasil, (2013)

155) GRJ (Governo do Estado do Rio de Janeiro), "Lei Orgânica do Município do Rio de Janeiro [Portuguese]", Rio de Janeiro, Brasil, (1990)

156) GRJ (Governo do Estado do Rio de Janeiro), "Dispõe sobre a Política Urbana e Ambiental do Município, institui o Plano Diretor de Desenvolvimento Urbano Sustentável do Município do Rio de Janeiro e dá outras providências [Portuguese]", Lei Complementar no 111 de 01/02/2011, Riode Janeiro, Brasil, (2011)

157) MVU (Ministerio de Vivienda y Urbanismo), "Ordenanza General de Urbanismo y Construcciones [Spanish]", Decreto Supremo No. 47 (1992), Santiago, Chile, (2017)

158) INN (Instituto Nacional de Normalizacion), "Calculation of the action of wind on structures [Spanish]", NCh 432. Of71, Santiago, Chile, (1971)

159) "General Law of Urban Planning and Constructions [Spanish]", Decreto con fuerza de ley No. 458 (1976), Santiago, Chile, (2017)

160) INN (Instituto Nacional de Normalizacion), "Structural design - Wind loads [Spanish]", NCh 432-2010, Santiago, Chile, (2010)

161) MAVDT (Ministerio de Ambiente, Vivienda y Desarrollo Territorial), "Reglamento Colombiano de Construcción Sismo Resistente NSR-10 [Spanish]", Decreto Numero 926 de 2010, Bogota, Colombia, (2010)

162) "Law by which norms on Earthquake Resistant Constructions are adopted [Spanish]", No. 400, Bogota, Colombia, (1997)

163) MIDUVI (Ministerio de Desarrollo Urbano y Vivienda), "Actualízate y oficialícese la Norma Ecuatoriana de la Construcción [Spanish]", Acuerdos 0047, Quito, Ecuador, (2015)

164) MIDUVI (Ministerio de Desarrollo Urbano y Vivienda), "Norma Ecuatoriana de la Construcción - Cargas (No Sismicas) [Spanish]", Codigo NEC-SE-CG, Quito, Ecuador, (2015)

165) PCEC (Presidente Constitucional de la República del Ecuador), "Estatuto del Regimen juridico Administrativo de la Funcion Ejecutiva, ERJAFE [Spanish]", Decreto Ejecutivo 2428, Quito, Ecuador, (2018)

166) JMA (Junta Municipal de Asuncion), "Reglamento General de Construcción [Spanish]", Ordenanza $\mathrm{N}^{\circ}$ 26.104/90, Asuncion, Paraguay, (1991)

167) INTN (Instituto Nacional de Technologia y Normalization), "Acción del Viento en las Construcciones [Spanish]", NP No 196, Asuncion, Paraguay, (1991)

168) "Municipal Organic Law [Spanish]", No 3966/2010, Asuncion, Paraguay, (2010)

169) MVCS (Ministerio de Vivienda, Construcción y Saneamiento), "Reglamento Nacional de Edificaciones 
[Spanish]", Decreto Supremo No 011, Lima, Peru, (2006)

170) "Law of Organization and Functions of the Ministry of Housing, Construction and Sanitation [Spanish]", No 27792, Lima, Peru, (2002)

171) "Building Ordinance [Dutch]", Paramaribo, Suriname, (1956)

172) RSR (Regering van Suriname), "Bouwbesluit no. 1 [Dutch]", Paramaribo, Suriname, (1956)

173) FONDONORMA (Fondo para la Normalización y Certificación de la Calidad), "Edificaciones Sismorresistentes - Parte 1: Articulado y Parte 2: Comentarios [Spanish]", COVENIN 1756-2:2001, Caracas, Venezuela, (2001)

174) COVENIN (Comisión Venezolana de Normas Industriales), "Acciones del Viento Sobre las Construcciones [Spanish]", COVENIN 2003-89, Caracas, Venezuela, (1989)

175) "Organic Law of the National System for Quality [Spanish]", No. 37.555, Caracas, Venezuela, (2002)

176) MIID (Ministry of Industry and Infrastructure Development), "The list of normative legal acts and normative technical documents in the field of architecture, urban planning and construction [Russian]", AGSK-1, Astana, Kazakhstan, (2020)

177) CCHULM (Committee for Construction, Housing and Utilities and Land Management), "Eurocode 1: Actions on structures - Part 1-4: General actions - Wind actions, with the National Annex [Russian]", SN RK EN 1991-1-4: 2005/2011, Astana, Kazakhstan, (2015)

178) "Law on Architectural, Urban Planning and Construction Activities [Russian]", No. 242, Astana, Kazakhstan, (2001)

179) MNE (Ministry of National Economy), "Rules for the formation and maintenance of architectural, urban planning and construction catalogs [Russian]", Order No. 701, Astana, Kazakhstan, (2015)

180) Gosstroy (State Agency for Architecture, Construction and Housing and Communal Services), "Normative and methodological documents for construction [Russian]", SK-1, Order No. 135, Bishkek, Kyrgyzstan, (2012)

181) USSR Gosstroy (Union of Soviet Socialist Republics State Committee for Construction), "Loads and Effects [Russian]", SNiP 2.01.07-85*, Moscow, Russia, (2005)

182) "Law on Technical Regulations "Safety of Buildings and Structures”[Russian]", No. 57, Bishkek, Kyrgyzstan, (2011)

183) GTJ (Government of Tajikistan), "List of normative technical documents (temporary technical regulations) [Russian]", Decree No. 704, Dushanbe, Tajikistan, (2009)
184) "Law on Technical Regulations [Russian]", No.5, Dushanbe, Tajikistan, (2009)

185) MCA (Ministry of Construction and Architecture), "List of building codes of Turkmenistan [Russian]", (2017), https://www.construction.gov.tm/tk/post/perechen-stroitel nyh-norm-turkmenistana/ (accessed February 17, 2018)

186) MCBMI (Ministry of Construction and Building Materials Industry), "Loads and Impacts. Design Standards [Russian]", TGK 2.01.07-2005, Resolution No. MK-23, Ashgabat, Turkmenistan, (2005)

187) "Law on Architectural Activity [Russian]", No. 496-V, Ashgabat, Turkmenistan, (2017)

188) Gosarkhitektstroy (State Committee for Architecture and Construction), "Index of current normative documents in the field of construction [Russian]", Tashkent, Uzbekistan, (2018)

189) Gosarkhitektstroy (State Committee for Architecture and Construction), "Loads and effects [Russian]", KMK 2.01.07-96, Tashkent, Uzbekistan, (1996)

190) "Law on Technical Regulations [Russian]", No. ZRU-213, Tashkent, Uzbekistan, (2009)

191) MHURD (Ministry of Housing and Urban-Rural Development), "Load Code for the Design of Building Structures", GB 50009-2012, Beijing, China, (2012)

192) "Standardization Law", No. 78, Beijing, China, (2017)

193) GHK (Government of Hong Kong), "Building (Construction) Regulations", Chapter 123B, Hong Kong, China, (2012)

194) GHK (Government of Hong Kong), "Buildings Ordinance", Chapter 123, Hong Kong, China, (2012)

195) BD (Buildings Department), "Practice Notes for Authorized Persons, Registered Structural Engineers and Registered Geotechnical Engineers", PNAP ADM-1, Hong Kong, China, (2009)

196) BD (Buildings Department), "Code of Practice on Wind Effects in Hong Kong and Explanatory Notes", Hong Kong, China, (2019)

197) GMO (Government of Macau), "Regulamento de Seguranca e Accoes em Estruturas de Edificios e Pontes [Portuguese]", Decreto-Lei n. ${ }^{\circ}$ 56/96/M, Macau, Portugal, (1996)

198) LECM (Civil Engineering Laboratory of Macau), "Regulamento de Seguranca e Accoes em Estruturas de Edificios e Pontes - Wind Action Revision (Consultation Document)", Macau, China, (2008)

199) MITW (Ministry of Interior), "Building Technical 
Regulations [Chinese]", Order No. 1070809006, Taipei, Taiwan, (2016)

200) CPAMI (Construction and Planning Agency), "Specifications and Explanations for Wind Resistant Design of Buildings [Chinese]", Taipei, Taiwan, (2014)

201) "Building Act", Taipei, Taiwan, (2011)

202) CJP (Cabinet of Japan), "Building Standard Law Enforcement Order", No. 338, Tokyo Japan, (2008)

203) MCJP (Ministry of Construction), "Stipulation of the method of calculating the value of $\mathrm{E}$ and the values of $\mathrm{V} 0$ and the wind force coefficient", Notification No. 1454, Tokyo, Japan, (2000)

204) MCJP (Ministry of Construction), "Stipulation of criteria for the structural calculation performed to confirm safety of structural capacity under wind load of roofing materials and claddings", Notification No. 1458, Tokyo, Japan, (2000)

205) "Building Standard Law", Tokyo, Japan, (2000)

206) AIJ (Architectural Institute of Japan), "Recommendations for Loads of Buildings [Japanese]", Tokyo, Japan, (2015)

207) MRTCUD (Ministry of Road, Transportation, Construction and Urban Development), "Climatic and geophysical parameters for construction [Mongolian]", BNbD 23-0109, Decree No. 169, Ulaanbaatar, Mongolia, (2009)

208) MCUD (Ministry of Construction and Urban Development), "Loads and Reactions [Mongolian]", BNbD 20-04-17, Decree No. 117, Ulaanbaatar, Mongolia, (2017)

209) GMN (Government of Mongolia), "General System of Norms and Normative Documents for Construction [Mongolian]", Resolution No. 106, Ulaanbaatar, Mongolia, (2019)

210) "Law on Construction [Mongolian]", Ulaanbaatar, Mongolia, (2016)

211) MASM (Mongolian Agency for Standardization and Metrology), "Loading and influences. General position [Mongolian]", MNS 3177:1981, Ulaanbaatar, Mongolia, (1981)

212) MLTMA (Ministry of Land, Transport and Maritime Affairs), "Building Structure Standards Rules [Korean]", Ordinance No. 206, Seoul, South Korea, (2009)

213) MLTMA (Ministry of Land, Transport and Maritime Affairs), "Building Structure Standards [Korean]", Notice No. 117, Seoul, South Korea, (2019)

214) "Building Law [Korean]", No. 16616, Seoul, South Korea, (2019)
215) MD (Ministry of Development), "Building Control Regulations, 2014", Bandar Seri Begawan, Brunei, (2014)

216) "Building Control Order, 2014", Bandar Seri Begawan, Brunei, (2014)

217) ABCi (Authority for Building Control and Construction Industry), "Building Guidelines and Requirements", PBD 12:2017, Bandar Seri Begawan, Brunei, (2017)

218) BSI (British Standards Institution), "Loading for buildings - Part 2. Code of practice for wind loads", BS 6399 Part 2:1997, London, United Kingdom, (1997)

219) BSI (British Standards Institution), "UK National Annex to Eurocode 1 - Actions on structures - Part 1-4: General actions - Wind actions", NA to BS EN 1991-1-4:2005+ A1:2010, London, United Kingdom, (2010)

220) GID (Government of Indonesia), "Peraturan Pelaksanaan Undang-Undang Tentang Bangunan Gedung [Indonesian]", No. 36, Jakarta, Indonesia, (2005)

221) "Law on Buildings [Indonesian]", No. 28, Jakarta, Indonesia, (2002)

222) KPU (Ministry of Public Works), "Guidelines for Building Technical Requirements [Indonesian]", No. 29/PRT/M/ 2006, Jakarta, Indonesia, (2006)

223) KPU (Ministry of Public Works), "Loading Design Guide for Homes and Buildings", SNI 03-1727-1989, Jakarta, Indonesia, (1989)

224) BSN (Badan Standardisasi Nasional), "Beban minimum untuk perancangan bangunan gedung dan struktur lain [Indonesian]", SNI 1727:2013, Jakarta, Indonesia, (2013)

225) "Street, Drainage and Building Act 1974", No. 133, Malaysia, Kuala Lumpur, (1974)

226) ILBS (International Law Book Services), "Uniform Building By-Laws 1984", Gazette Notification No. 5178/85, Petaling Jaya, Malaysia, (2013)

227) GJH (Government of Johor), "Undang-Undang Kecil Bangunan Seragam 1986 [Malay]", Johor Pemberitahu Undangan No. 17, Johor Bahru, Malaysia, (2012)

228) MFT (Ministry of Federal Territories), "Building (Federal Territory of Kuala Lumpur) By-Laws 1985 [Malay]", Invitation Notifier (A) No. 537, Kuala Lumpur, Malaysia, (1985)

229) GSW (Government of Sarawak), "Buildings Ordinance, 1994", Kuching, Malaysia, (2008)

230) DSM (Department of Standards Malaysia), "Code of Practice on Wind Loading for Building Structure", MS 
1553:2002, Putrajaya, Malaysia, (2002)

231) MLG (Government of Melaka), "Uniform Building ByLaws (Amendment) 2019 [Malay]", Melaka Pemberitahu Undangan No. 14, Melaka, Malaysia, (2019)

232) GSG(Government of Selangor), "Selangor Uniform Building (Amendment) (No. 2) By-Laws 2012", Selangor Pemberitahu Undangan No. 142, Shah Alam, Malaysia, (2012)

233) PPH (President of the Philippines), "National Building Code of the Philippines", Decree No. 1096, Manila, Philippines, (2005)

234) ASEP (Association of Structural Engineers of the Philippines), "National Structural Code of the Philippines", NSCP C101-15, Quezon City, Philippines, (2015)

235) NBCDO (National Building Code Development Office), "Implementing Rules and Regulations of the National Building Code of the Philippines (PD 1096)", Manila, Philippines, (2005)

236) MND (Ministry of National Development), "Building Control Regulations 2003", No. S 666, Singapore, (2003)

237) "Building Control Act", Chapter 29, Singapore, (2015)

238) BCA (Building and Construction Authority), "Approved Document - Acceptable Solutions", Singapore, (2019)

239) SPRING-SG (Standards, Productivity and Innovation Board), "Singapore National Annex to Eurocode 1: Actions on structures - Part 1-4: General actions - Wind actions", NA to SS EN 1991-1-4:2009, Singapore, (2009)

240) MITH (Ministry of Interior), "Regulations No. 6 (2527) issued under the Building Control Act 2552 [Thai]", Bangkok, Thailand, (1984)

241) "Building Control Act 2522 [Thai]", Bangkok, Thailand, (1979)

242) DPWTP (Department of Public Works and Town Planning), "Wind Loading Calculation and Response of Buildings [Thai]", DPT 1311-50, Bangkok, Thailand, (2007)

243) MCVN (Ministry of Construction), "Building Code of Vietnam - Volumes II and III [Vietnamese]", Decision No: 439/BXD-CSXD, Hanoi, Vietnam, (1997)

244) MST (Ministry of Science and Technology), "Loads and effects - Design standard", TCVN 2737:1995, Hanoi, Vietnam, (1996)

245) MCVN (Ministry of Construction), "Vietnam Building Code - Natural Physical \& Climatic Data for Construction [Vietnamese]", QCVN 02:2009/BXD, Hanoi, Vietnam, (2009)
246) GVN (Government of Vietnam), "Functions, Tasks and Organizational Structure of the Ministry of Construction [Vietnamese]", Decree No. 15-CP, Hanoi, Vietnam, (1994) 247) MHPW (Ministry of Housing and Public Works), "Bangladesh National Building Code", Statutory Regulatory Order No. 55, Dhaka, Bangladesh, (2020)

248) "Building Construction Act, 1952", East Bengal Act No. II, Dhaka, Bangladesh, (1953)

249) MWHS (Ministry of Works and Human Settlement), "Bhutan Building Regulation 2018", Thimphu, Bhutan, (2018)

250) "Local Government Act, 2009", Thimphu, Bhutan, (2009)

251) MWHS (Ministry of Works and Human Settlement), "Building Code of Bhutan 2018", Thimphu, Bhutan, (2018)

252) BIS (Bureau of Indian Standards), "Code of Practice for Design Loads (other than earthquake) for Buildings and Structures - Part 3: Wind Loads", IS 875 (Part 3):1987, New Delhi, India, (2007)

253) BIS (Bureau of Indian Standards), "National Building Code of India", New Delhi, India, (2016)

254) BIS (Bureau of Indian Standards), "Code of Practice for Design Loads (other than earthquake) for Buildings and Structures - Part 3: Wind Loads", IS 875 (Part 3):2015, New Delhi, India, (2015)

255) GAP (Government of Andhra Pradesh), "Andhra Pradesh Building Rules, 2017", Order (Ms) No. 119, Hyderabad, India, (2017)

256) GKA (Government of Karnataka), "Karnataka Municipal Corporations Model Building Bye-Laws 2017", NotificationI No. UDD 14 TTP 2017(P-3), Bengaluru, India, (2017)

257) GMH (Government of Maharashtra), "Comprehensive Building By-laws applicable to Planning Authorities in the State", Resolution No. TPS-1817/501/CR-58/17/UD-13, Mumbai, India, (2018)

258) GTN (Government of Tamil Nadu), "Tamil Nadu Combined Development and Building Rules, 2019", Order (Ms) No. 18, Chennai, India, (2019)

259) GWB (Government of West Bengal), "West Bengal Municipal (Building) Rules, 2007", Notification No. 67/MA/O/C-4/3R-8/2002, Kolkata, India, (2007)

260) DDA (Delhi Development Authority), "Unified Building Bye Laws for Delhi 2016", Starutory Order No. 1191(E), Deli, India, (2016)

261) BIS (Bureau of Indian Standards), "National Building Code of India", New Delhi, India, (2005) 
262) BUDHD (Bihar Urban Development and Housing Development), "Bihar Building Bye-Laws 2014", Patna, India, (2014)

263) JUDHD (Jharkhand Urban Development and Housing Development), "Jharkhand Building Bye-Laws 2016", Ranchi, India, India, (2016)

264) NBCRO (National Building Control Regulations Office), "National Building Regulations - Part 6. Design Loads for Buildings [Farsi]", Tehran, Iran, (2013)

265) "Law on Engineering System and Building Control [Farsi]", Legal Notice No. 4775-Q, Tehran, Iran, (1995)

266) ISIRI (Institite of Standards and Industrial Research of Iran), "Minimum Design Loads in Buildings and Other Structures with Amendments [Farsi]", ISIRI 519:1996, Tehran, Iran, (1996)

267) MCPI (Ministry of Construction and Public Infrastructure), "Maldives National Building Code", Male, Maldives, (2008)

268) "Construction Act", No. 4, Male, Maldives, (2017)

269) MCPI (Ministry of Construction and Public Infrastructure), "Approved Document for Maldives National Building Code - Structure Clause B1 and Durability Clause B2", Male, Maldives, (2007)

270) MPPW (Ministry of Physical Planning and Works), "Nepal National Building Code - Wind Load", NBC 104:1994, Kathmandu, Nepal, (2008)

271) "Building Act, 2055 (1998)", No.2, Kathmandu, Nepal, (2006)

272) MHW (Ministry of Housing and Works), "Building Code of Pakistan (Seismic Provisions - 2007)", BCP SP-2007, Islamabad, Pakistan, (2007)

273) CCPB (Council for Codes of Practice for Buildings), "Code of Functional Requirements of Buildings - Chapter V: Loading", CP3: Chapter V, London, United Kingdom, (1952)

274) CDA (Capital Development Authority), "Islamabad Building Regulations, 1963", Islamabad, Pakistan, (1963)

275) CDA (Capital Development Authority), "The Islamabad Capital Territory Residential Sectors Zoning (Building Control) Regulations - 2020", Statutory Regulatory Order No. 1575(I)/2019, Islamabad, Pakistan, (2019)

276) LGERDD (Local Government, Elections and Rural Development Department), "Khyber Pakhtunkhwa Model Building Bye-laws, 2017", No. SOG/LG/8-133/ Advertisement/ 2017, Peshawar, Pakistan, (2017)
277) HTPD (Housing and Town Planning Department), "Karachi Building and Town Planning Regulations 2002", No. SO (Land) HTP/KBCA-3-39/2000, Karachi, Pakistan, (2002)

278) ICC (International Code Council), "International Building Code", IBC 2006, Washington, D.C., United States, (2006)

279) LDA (Lahore Development Authority), "LDA Building and Zoning Regulations (2019)", No. LDA/C\&I/3798, Lahore, Pakistan, (2019)

280) JICA (Japan International Cooperation Agency), "Project Formulation Study on Disaster Management for the Islamic Republic of Pakistan [Japanese]", JR 08-003, Tokyo, Japan, (2008)

281) MUD (Ministry of Urban Development), "Normative Acts Regulations [Armenian]", Order No. 82, Yerevan, Armenia, (2001)

282) USSR Gosstroy (Union of Soviet Socialist Republics State Committee for Construction), "Loads and Effects [Russian]", SNiP 2.01.07-85, Moscow, Russia, (1988)

283) MUD (Ministry of Urban Development), "Construction Norms “Construction Climatology” [Armenian]", HHSHN II-7.01-2011, Order No. 167-N, Yerevan, Armenia, (2011)

284) "Law on Urban Development [Armenian]", No. HO-211, Yerevan, Armenia, (1998)

285) FHN/ARXKOM (Ministry of Emergency Situations and State Committee for Urban Planning and Architecture), "List of normative documents on urban planning and construction in force [Azerbaijani]", Baku, Azerbaijan, (2019)

286) ARXKOM (State Committee for Urban Planning and Architecture), "Loads and Effects. Design Norms [Azerbaijani]", AzDTN 2.1-1, Baku, Azerbaijan, (2015)

287) "Urban Building and Construction Code [Azerbaijani]", Chapter 1, Baku, Azerbaijan, (2014)

288) CMCY (Council of Ministers), "Road and Building (Amending) Regulations [Greek]", Regulatory Administrative Act 479/2011, Nicosia, Cyprus, (2011)

289) CYS (Cyprus Organization for Standardization), "Cyprus National Annex to Eurocode 1: Actions on structures - Part 1-4: General actions - Wind actions", NA to CYS EN 1991-1-4:2005, Nicosia, Cyprus, (2010)

290) "Road and Building Regulations Law [Greek]", Chapter 96, Nicosia, Cyprus, (1959)

291) MESD (Ministry of Economy and Sustainable Development), "Construction norms and rules of technical regulation and other documents [Kartuli]", Order No. 1-1/251, Tbilisi, 
Georgia, (2011)

292) MESD (Ministry of Economy and Sustainable Development), "Design Norms "Construction Climatology" [Kartuli]", PN 01.05-08, Tbilisi, Georgia, (2008)

293) "Law on Normative Acts [Kartuli]", No. 1876, Tbilisi, Georgia, (2009)

294) "Law on Construction Activities [Kartuli]", No 577, Tbilisi, Georgia, (2000)

295) COSQC (Central Organization for Standardization and Quality Control), "Code of Loads and Forces - Part 2: Loads [Arabic]", Baghdad, Iraq, (2016)

296) "Law on Central Organization for Standardization and Quality Control [Arabic]", No. 54, Bagdad, Iraq, (1979)

297) MIIL (Ministry of Interior), "Planning and Building Regulations (Application for a Permit, its Conditions and Fees), 5730-1970 [Hebrew]", Tel Aviv, Israel, (1970)

298) SII (Standards Institution of Israel), "Characteristic Loads in Structures: Wind Loads [Hebrew]", SI 414:2008, Tel Aviv, Israel, (2009)

299) "Planning and Building Law, 5725-1965 [Hebrew]", Tel Aviv, Israel, (1965)

300) NCCJ (National Construction Council of Jordan), "Jordanian National Building Code - Loads and Forces [Arabic]", Amman, Jordan, (2006)

301) NCCJ (National Construction Council of Jordan), "Instructions of Codes Application at the Design, Implementation, Supervision, Maintenance \& Operation Phases and Public Safety Works and all Engineering Works in Relation thereto of 2004 [Arabic]", Amman, Jordan, (2005)

302) "National Construction Law [Arabic]", No. 7 of 1993, Amman, Jordan, (1993)

303) CMLB (Council of Ministers), "Public Safety Law [Arabic]", Decree No. 7964, Beirut, Lebanon, (2012)

304) GLB (Government of Lebanon), "Construction Law [Arabic]", Legislative Decree No. 646, Beirut, Lebanon, (1983)

305) LIBNOR (Lebanese Standards Institution), "Calculation of wind loads on structures", NL 137:2013, Beirut, Lebanon, (2013)

306) PNA (Palestinian National Authority), "Multi-storey building system in the Gaza Strip [Arabic]", Ram Allah, Palestine, (1994)

307) PNA (Palestinian National Authority), "Town Planning Law [Arabic]", No. 28, Ram Allah, Palestine, (1936)
308) MEQA (Ministry of Environment), "Qatar Construction Specifications", Decision No. 210/2014, Doha, Qatar, (2014)

309) "Law on Building Regulations [Arabic]", No. 4, Doha, Qatar, (1985)

310) SBCNC (Saudi Building Code National Committee), "Saudi Building Code - Loads and Forces Requirements [Arabic]", SBC 301, Riyadh, Saudi Arabia, (2018)

311) SBCNC (Saudi Building Code National Committee), "Implementing Regulation of the Saudi Building Code [Arabic]", Royal Decree No.(M/43), Riyadh, Saudi Arabia, (2017)

312) DGC (Damascus Governorate Councill), "Damascus Building Code [Arabic]", Decision No. 492, Damascus, Syria, (1997)

313) GSY (Government of Syria), "Local Administration Law [Arabic]", Legislative Decree 107, Damascus, Syria, (2011)

314) SEA (Syrian Engineers Association), "Syrian Arab Code for the Design and Implementation of Reinforced Concrete Structures - Appendix (1) Loads on Buildings [Arabic]", Damascus, Syria, (2006)

315) SEA (Syrian Engineers Association), "Syrian Arab Code for the Design and Implementation of Reinforced Concrete Structures [Arabic]", Damascus, Syria, (2012)

316) MPWS (Ministry of Public Works and Settlement), "Regulation for Buildings to be built in Disaster Areas [Turkish]", Official Gazette No. 23098, Ankara, Turkey, (1997)

317) CMTR (Council of Ministers), "Law No. 7269 on Aid and Measures to be taken due to Disasters affecting Public Life [Turkish]", Ankara, Turkey, (1969)

318) IBBIM (Istanbul Metropolitan Municipality Building Directorate), "Istanbul High Buildings Wind Regulations [Turkish]", Istanbul, Turkey, (2009)

319) TSE (Turkish Standards Institution), "Design loads for buildings [Turkish]", TS 498:1997, Ankara, Turkey, (1997)

320) GAE (Government of Abu Dhabi), "Law regulating Building Works", No. 4, Abu Dhabi, United Arab Emirates, (1983)

321) GAE (Government of Abu Dhabi), "Abu Dhabi International Building Codes", (2014), https://dmat.abud habi.ae/_data/ADC2014/AD_Building_Code/index.html (accessed September 29, 2020)

322) GRK (Government of Ras Al Khaimah), "Ras Al Khaimah 
Building Code [Arabic]", Decision No. 18, Ras alKhaimah, United Arab Emirates, (2018)

323) GDU (Government of Dubai), "Building Code Regulations and Construction Specifications", Administrative Resolution No. 125, Dubai, United Arab Emirates, (2001)
324) GDU (Government of Dubai), "Wind and earthquake loads [Arabic]", Circular No. 191, Dubai, United Arab Emirates, (2013)

325) GDU (Government of Dubai), "Dubai Wind Code", Draft Copy, Dubai, United Arab Emirates, (2013) 